УДК 782.1

\author{
Инь Цзяюань \\ соискатель кафедры теории музыки \\ и композиции Одесской национальной \\ музыкальной академии им. А. В. Неждановой \\ odma_n@ukr.net
}

\title{
ОПЕРА-БАЛЕТ В. ГУБАРЕНКО «ВИЙ»: НЕКОТОРЫЕ СЕМАНТИЧЕСКИЕ АСПЕКТЫ ИНТЕРПРЕТАЦИИ ГОГОЛЕВСКОГО СЮЖЕТА
}

Цель исследования - выявление посредством осуществления детального семантического анализа ранее неизученных особенностей прочтения В. Губаренко в опере «Вий» гоголевского первоисточника. Методологическая база работы опирается на опыт отечественной и зарубежной исследовательской классики (труды Б. Асафьева, И. Драч, М. Нестьевой, В. Холоповой, М. Черкашиной и др.). Среди методов исследования превалирует традиционный музыковедческий анализ. Научная новизна заключается в раскрытии новых смысловых граней предложенной В. Губаренко оперной интерпретации известного гоголевского сюжета. Основные выводы сводятся к выявлению общих и отличных черт в драматургии и концепции оперы В. Губаренко и повести Н. Гоголя. Среди оригинальных приемов, используемых композитором, признается прием многократного помещения одних и тех же словесных (гоголевских) конструкций в разный смысловой контекст. Основу поэтики рассматриваемой оперы формирует диалог (с элементами взаимопроникновения) смехового и серьезного, реального и потустороннего, добра и зла.

Ключевые слова: музыкальная драматургия, интерпретация, народная образная сфера, словесный лейтмотив, хор, балетный персонаж.

In' Tsyayuan', applicant of the department theory of music and composition of the Odessa national A. V. Nezhdanova academy of music

V. Gubarenko opera-balet «Viy»: some semantic aspects of the Gogol plot's interpretation

Article purpose is to identify through semantic analysis previously unexplored features of V. Gubarenko opera «Viy» interpretation of the Gogol primary source. Methodological base of the work is based on the experience of domestic and foreign research classics (works of B. Asafyev, I. Drach, M. Nestieva, V. Holopova, M. Cherkashina, etc.). Traditional musicological analysis prevails among methods of research. Scientific novelty concludes in the discovery of new semantic facets of $V$. Gubarenko's operatic interpretation of the famous Gogol novelette. Main conclusions are reduced to the identification of common

(C) Инь Цзяюань, 2017 
and distinct traits in drama and concept of V. Gubarenko opera by and N. Gogol story. Among the original techniques used by the composer is the acceptance of repeated placement of the same verbal (Gogolian) constructions in different semantic contexts. The basis of the opera poetics forms a dialogue (with elements of interpenetration) of funny and serious, real and otherworldly, good and evil.

Keywords: musical dramaturgy, interpretation, folk image sphere, verbal leitmotiv, chorus, ballet character.

Інь Цзяюань, здобувач кафедри теорії музики та композиції Одеської національної музичної академії імені А. В. Нежданової

Опера-балет В. Губаренка «Вій»: деякі семантичні аспекти інтерпретації гоголівського сюжету

Мета дослідження - виявити за допомогою проведення семантичного аналізу раніше невивчені особливості прочитання В. Губаренком в опері «Вій» гоголівського першоджерела. Методологічна база роботи спирається на досвід вітчизняної і зарубіжної дослідницької класики (праці Б. Асаф'єва, І. Драч, М. Нестьєвої, В. Холопової, М. Черкашиної та ін.). Серед методів дослідження превалює традиційний музикознавчий аналіз. Наукова новизна полягає в розкритті нових смислових граней запропонованої В. Губаренком оперної інтерпретації відомого гоголівського сюжету. Основні висновки зводяться до виявлення загальних і відмінних рис в драматургії і концепції опери В. Губаренка та повісті М. Гоголя. Серед оригінальних прийомів, які використовуває композитор, визнається прийом багаторазового використання одних і тих самих словесних (гоголівських) конструкцій в різних смислових контекстах. Основу поетики опери формує діалог (з елементами взаємопроникнення) смехового і серйозного, реального і потойбічного, добра $і$ зла.

Ключові слова: музична драматургія, інтерпретація, народна образна сфера, словесний лейтмотив, хор, балетний персонаж.

Анализ исследований и публикаций позволяет говорить о том, что написанная в 1980 году по сюжету одноименной повести Н. Гоголя опера-балет В. Губаренко «Вий» в музыковедческой литературе освещена далеко не полно. Научные изыскания М. Нестьевой, автора статьи о первой, одесской постановке сочинения (1984г.), И. Драч, затрагивающей вопросы концепции оперы «Вий» в монографии, посвященной творчеству В. Губаренко, и, наконец, емкие, но фрагментарные высказывания об этом произведении в работах М. Черкашиной $[9 ; 10 ; 5 ; 12 ; 13]$ для целостного представления о нем, на наш взгляд, недостаточны, что делает изучение этой оперы по-прежнему актуальным - в контексте исследования проблем современной украинской оперной поэтики. Поэтому, опираясь на уже выработанные положения, мы поставили перед собой цель - выявить посредством 
осуществления детального семантического анализа ранее неизученные особенности прочтения В. Губаренко в опере «Вий» гоголевского первоисточника. Объект исследования - жанрово-тематические направления современной украинской оперы. Предмет исследования - жанровое решение, концепция и драматургия оперы-балета В. Губаренко «Вий». Научная новизна заключается в раскрытии новых смысловых граней предложенной Губаренко оперной интерпретации известного гоголевского сюжета.

Изложение основного материала. Либреттисты оперы-балета В. Губаренко «Вий» М. Черкашина и Л. Михайлова в тесном сотрудничестве с композитором создали свою версию гоголевского сюжета. Либретто состоит как из собственно «гоголевских» строк (слов самих персонажей повести и «от автора»), так и из значительного по объему текста, сочиненного «авторским коллективом» оперы. Как отмечает И. Драч, исторический колорит прошлого создали заимствование и обработка текстового материала из украинской литературы XVIIXVIII столетий - «псалмов, стихов-травестий, интермедий вертепного и школьного театра» $[5,10]$.

Так, Пролог и I акт являются добавленными к сюжетному ряду сочинения Гоголя: либреттистами значительно расширяется данное писателем в начале повести краткое описание быта бурсаков.

Действие Пролога происходит в семинарии. Отпущенные на каникулы семинаристы радуются долгожданной свободе; их бурное веселье нарушает внезапное появление ректора. События I акта разворачиваются на фоне городской ярмарки. Среди торговых рядов появляются Сотник, его дочь с нянькой, Дорош и Свирид. Тит, Тиберий и Хома Брут разыгрывают перед всем честным народом театральное представление - комедию «Про Адама и Еву». Хома, играющий роль Ангела, увидев в толпе зрителей Панну, произносит страстный монолог о ее необыкновенной красоте. Сотникивна влюбляется в красноречивого юношу и, спрятавшись, следит за его заигрываниями с Бубличницей. Завершает акт веселая каникулярная песня бурсаков.

Ход событий во втором и третьем действиях соответствует сюжетной канве первоисточника. Приключения Тита, Тиберия и Хомы, заблудившихся в степи, сменяют полет Хомы и оседлавшей его Ведьмы, затем избиение Панны Брутом (II акт), смерть Сотникивны, оплакивание отцом любимой дочери, и, наконец, гибель Хомы, столкнувшегося «лицом к лицу» с нечистой силой (III акт). 
Завершающий гоголевскую повесть диалог Тита и Тиберия о судьбе Хомы (Эпилог в опере) происходит, согласно замыслу либреттистов, в ночь на Ивана Купала. Радостная Купальская как гимн жизни венчает оперу.

Это очень важное, на наш взгляд, изменение. Гоголь сводит свое повествование о трагической судьбе Хомы к шутке. Всего-то, что нужно было сделать философу, - «не побояться» и «плюнуть на хвост» ведьме - и уж после этого ничего она Хоме и не сделает. В конце концов, «все бабы, что сидят на базаре в Киеве, - ведьмы» $[2,184]$.

В. Губаренко, сохраняя эти фразы в либретто, дает народный хоровой финал - арку к массовому первому действию, помещая между этими яркими, красочными, жизнерадостными эпизодами историю трагической гибели Хомы. Таким образом, данная сюжетная последовательность объясняется стремлением композитора отразить, с одной стороны, идею скоротечности жизни, когда многие события, происходящие даже с близкими нам людьми, не только не вызывают у нас необходимой (в общечеловеческом смысле) соответствующей адекватной реакции, но и иногда не успевают попасть в поле нашего зрения. С другой стороны, улавливая в отношении самого Н. Гоголя к событиям, описанным им якобы с чьих-то слов, некоторую долю иронии, Губаренко смело сопоставляет по принципу контраста эпизод страшной смерти Хомы и веселый, праздничный финал, демонстрируя условность всего происходящего.

II, III акты изобилуют изменениями в тексте первоисточника - в данном случае сокращениями и перестановками. Например, в разговор Тита, Тиберия и Хомы из начала II действия оперы включен рассказ о Миките, загубленном Панною, тогда как в повести мы узнаем о судьбе несчастного псаря из казацкой беседы, происходившей на кухне в доме Сотника (этот эпизод опущен в либретто как не влияющий на развитие сюжетной линии).

В том же II акте Хома, оставшись один после того, как Старуха устроила его на ночлег, исполняет лирическую песню, мечтая о большой любви, тогда как у Гоголя философ лишь «поворотился на другой бок, чтобы заснуть мертвецки». Этот эпизод введен в либретто потому, что, согласно замыслу композитора, философ и Панна, встретившись во время представления на ярмарке, с первого взгляда полюбили друг друга. Таким образом, в первой картине (она же I акт) происходит завязка драматического любовного конфликта, во 
второй картине (II акт) - как раз в сцене «Старуха - Хома», и далее, в балетной сцене полета, - его развитие (драматическая кульминация приходится на четвертую картину третьего действия - отпевание Хомой Панны). Поэтому Хома в своем единственном сольном номере уже переполнен еще неосознанным им самим пока чувством. В повести к этому моменту действия философ пока не знает о существовании дочки Сотника, он очень устал с дороги и мечтать может только о том, чтобы поскорее заснуть.

В третьей картине III акта благодаря использованию киноприема «смены кадра» действие попеременно происходит то в доме Сотника, где оплакивают умершую Панну, то у Бубличницы, в доме которой на диване нежится сытый и довольный Хома. Контраст драматического и комического создает колоссальное психологическое воздействие на зрителя-слушателя. Картина завершается соединением обоих планов благодаря введенному композитором единому тематическому и музыкальному материалу (все действующие лица хором исполняют песню-реквием «Да заболело тело бурлацкое»).

Тексты хоров и Бубличницы введены либреттистами. Кстати, Бубличница как действующее лицо отсутствует в повести. В опере эта героиня выступает как собирательный образ простой женщины, преподнесенный композитором в той любовно-юмористической манере, которую выработал в создании народных образов и использовал, в частности, в «Вие», сам Н. Гоголь.

Семантически важной является фраза, отсутствующая в повести, но звучащая в опере: «Встань, подымись, дочь любимая, сжалься над горем отца» (проводится дважды - см. хор девушек и партию Сотника - картина третья, цифра 304). Возможно, этот призыв, по замыслу композитора, становится одной из причин «оживания» Панны в обличье Ведьмы в церкви (четвертая картина третьего действия).

Текст Хомы из четвертой картины состоит из фраз, взятых авторами либретто из повести, а именно: из той сцены, где Брут видит мертвую Панну в одной из комнат ее дома и узнает в ней избитую им Ведьму, и из сцены, в которой философ читает молитвы по усопшей в первую ночь (у Губаренко Хома проводит в церкви всего одну ночь, тогда как у Гоголя - три). Здесь же - значительно сокращенные и объединенные в один два разговора, состоявшиеся между Сотником и Хомой в повести. Все эти изменения связаны с потребностью адаптации текста первоисточника к новым условиям, диктуемым ком- 
позиторским замыслом. Введение купюр оказалось необходимым, поскольку перечисленные эпизоды не обогащали сюжет новой информацией и лишь «затягивали» бы активное развитие действия оперы, уже стремящегося к развязке.

Обращает на себя внимание интересная, на наш взгляд, с музыкальной и сценической точки зрения находка композитора и либреттистов в этой же четвертой картине. После крика Ведьмы: «Приведите Вия!.» - «наступает тишина, движения балета, как при замедленных съемках, вместо ликов икон в разных местах проступают знакомые лица Бубличницы, Дороша, Свирида, Старухи» (см. цифру 401 и далее). При этом некоторые фразы, звучащие в партиях этих героев, уже встречались в опере ранее ${ }^{1}$ :

\begin{tabular}{|l|l|}
\hline Ц. 401, ІІІ действие, картина 4-я: & \\
Бубличница: - Здравствуй, Хома! & \\
А-я-яй! Что это с тобой? \\
Дорош: - Молчи, глупая баба! \\
Бубличница: - Ах, Боже мой, да он \\
весь поседел. \\
Старуха: - Э-ге-ге, и правда посе- \\
дел... ляжешь под навесом, там сено & \\
сложено и воздух свежий - дыши на & укладывает на ночлег Хому. \\
здоровье. & Партия Старухи. \\
\hline Свирид: - Вот старая ведьма! & Ц. 212 - там же. Партия Хомы. \\
Дыши, раз в брюхе пусто. & \\
\hline Ц. 409, ІІІ действие, картина 4-я & \\
(одновременно): & \\
Бубличница: - Не смотри, Хома, \\
зажмурь глаза, спрячь голову, нель- \\
зя смотреть, нельзя смотреть, \\
нельзя смотреть, нельзя смотреть! \\
Свирид: - Ах, Боже мой, Боже мой, \\
бурсак, нельзя смотреть, \\
$\begin{array}{l}\text { нельзя смотреть! } \\
\text { Дорош: - Тише, жено, почто во- } \\
\text { пишь, аки окаянна. }\end{array}$ & \\
\hline
\end{tabular}

В этой сцене перед Хомой, уже понимающим, что его смерть близка, и находящимся на грани безумия после всего того, что ему пришлось увидеть и пережить, словно проносятся различные эпизоды из его жизни, лица людей, с которыми он когда-то встречался, отрывки из бесед с ними. Причем события «перетасовываются» - 
слова, принадлежащие ранее одним героям, звучат в данном эпизоде в партии других, создавая эффект нереальности, фантасмагории. Изъятые из комедийно-бытового контекста и перенесенные в музыкально-сценическое пространство драматической кульминации оперы и таким образом помещенные в новый смысловой контекст, приведенные фразы придают происходящему более зловещий оттенок, чем танцы нечистой силы, которые предшествовали рассматриваемому эпизоду.

Драматургия оперы строится на объединении, точнее, создании синкретического единства реального и иллюзорного, бытового и воображаемого, «смешного» (народные образы) и «страшного» (потусторонняя сфера, представленная как «создание простонародного воображения» ${ }^{2}$ ), в целом, в соответствии с эстетикой Гоголя, в произведениях которого, и не только в «Вие», серьезный тон соседствует с искрометным юмором, трагедия - с комедией, а события воображаемые, невероятные переплетаются с реальными, вплетаются в них как их органическая составляющая.

Приведенный выше прием переклички фраз не является в опере единичным. Все музыкально-сценическое развитие пронизывает словесный лейтмотив со словом «красота», от первого появления Сотникивны на ярмарке вплоть до сцены в церкви, до того момента, как Хома узнает в усопшей Панне избитую им Ведьму:

\begin{tabular}{|c|c|c|c|}
\hline \multirow[t]{3}{*}{ I действие } & $\begin{array}{l}\text { Ц. } 60 \\
\text { клавира }\end{array}$ & $\begin{array}{l}\text { Стецько на } \\
\text { ярмарке - о } \\
\text { Панне: }\end{array}$ & $\begin{array}{l}\text { - Гляди, краса какая, глаз не отор- } \\
\text { вать, аж запекло в груди и занемели } \\
\text { ноги. Ой, лишенько, ой, грех какой! }\end{array}$ \\
\hline & $\begin{array}{l}\text { Ц. } 98 \\
\text { клавира }\end{array}$ & $\begin{array}{l}\text { Хома-Ан- } \\
\text { гел - Пан- } \\
\text { не: }\end{array}$ & $\begin{array}{l}\text { - Женская красота есть тайна... } \\
\text { Манишь, потопляешь, в тенета свои } \\
\text { уловляешь. }\end{array}$ \\
\hline & $\begin{array}{l}\text { Ц. } 133 \\
\text { клавира }\end{array}$ & $\begin{array}{l}\text { Сотник - } \\
\text { Панне: }\end{array}$ & $\begin{array}{l}\text { - ...и выбрать красоте твоей наряд } \\
\text { к лицу. }\end{array}$ \\
\hline \multirow[t]{3}{*}{ II действие } & $\begin{array}{l}\text { Ц. } 183 \\
\text { клавира }\end{array}$ & $\begin{array}{l}\text { Тит - о } \\
\text { ведьмах: }\end{array}$ & $\begin{array}{l}\text { - Ее, бывает, с виду не узнаешь, } \\
\text { посмотришь - красавица, аж дух } \\
\text { захватит... Рассказывал недавно } \\
\text { один подпасок про дочку Сот- } \\
\text { ника... }\end{array}$ \\
\hline & $\begin{array}{l}\text { Ц. } 259 \\
\text { клавира }\end{array}$ & $\begin{array}{l}\text { Хома (по- } \\
\text { лет): }\end{array}$ & $\begin{array}{l}\text { - Страшно и прекрасно, давит и } \\
\text { томит. }\end{array}$ \\
\hline & $\begin{array}{l}\text { Ц. } 265 \\
\text { клавира }\end{array}$ & $\begin{array}{l}\text { Хома (после } \\
\text { избиения } \\
\text { Панны): }\end{array}$ & $\begin{array}{l}\text { - Красавица Панна в расцвете } \\
\text { юных лет. }\end{array}$ \\
\hline
\end{tabular}




\begin{tabular}{|c|c|c|c|}
\hline III действие & $\begin{array}{l}\text { Ц. } 280 \\
\text { клавира }\end{array}$ & $\begin{array}{l}\text { Бублични- } \\
\text { ца - Хоме } \\
\text { (Andante } \\
\text { amoroso): }\end{array}$ & $\begin{array}{l}\text { - Сладость моя, красота ненагляд- } \\
\text { ная! }\end{array}$ \\
\hline & $\begin{array}{l}\text { Ц. } 303 \\
\text { клавира }\end{array}$ & $\begin{array}{l}\text { Сотник } \\
\text { (оплакивает } \\
\text { Панну): }\end{array}$ & $\begin{array}{l}\text { - Краса твоя не на радость отцу } \\
\text { расцвела - тлеть ей в сырой земле. }\end{array}$ \\
\hline & $\begin{array}{l}\text { Ц. } 364 \\
\text { клавира }\end{array}$ & $\begin{array}{l}\text { Хома (в } \\
\text { церкви): }\end{array}$ & $\begin{array}{l}\text { - Говорят, она красавица, каких не } \\
\text { бывало на свете. }\end{array}$ \\
\hline & $\begin{array}{l}\text { Ц. } 366 \\
\text { клавира }\end{array}$ & $\begin{array}{l}\text { Хома и } \\
\text { хор - о } \\
\text { мертвой } \\
\text { Панне: }\end{array}$ & $\begin{array}{l}\text { - Красота! Какая красота! Незем- } \\
\text { ная, сверкающая красота!... }\end{array}$ \\
\hline & & Хома: & $\begin{array}{l}\text {-...Но отчего же душа так заныла } \\
\text { страшно, и странный трепет меня } \\
\text { сковал? }\end{array}$ \\
\hline
\end{tabular}

Слово «красота» наделяется различной смысловой нагрузкой: красота Панны-Ведьмы, притягивающая, страшная, губящая Хому, бесовская «красота ощущений» от их совместного полета, и - вполне реальная, человеческая красота философа в глазах влюбленной в него Бубличницы. И, все же словесный лейтмотив связан, прежде всего, с образом Сотникивны - именно ее неземная «злая» краса завораживает Хому, и приводит, в конечном итоге, к смерти обоих главных героев оперного действа - и философа, и Панны.

В опере использован также прием повторности сценического комплекса. Так, Хому-философа, появляющегося в Прологе, «заменяет» ставший философом Тиберий ${ }^{3}$. Происходит своего рода завершение цикла, возвращение на круги своя. В этом отношении знаменателен открывающий и завершающий оперу народный хор (в Прологе - хор бурсаков, в Эпилоге - всенародный «На Ивана Купала»), прославляющий жизнь во всей ее полноте, продолжающуюся несмотря ни на что.

В первом действии перекликаются эпизоды «Хома впервые видит Панну» и «Хома любезничает с Бубличницей». В обращении к обеим особам женского пола использованы одни и те же фразы и один музыкальный материал. Отличается манера исполнения: в первом случае - ремарка religioso, во втором случае - более экспрессивно, на $F$ (см. цифру 149 клавира: «Хома... атакует пышнотелую красавицу»). Усилению комического эффекта в последнем эпизоде способствует 
сопоставление «высокого», возвышенного слога, которым изъясняется Хома, и простонародной речи Бубличницы. Впрочем, философ, произнеся несколько фраз из монолога, посвященного Панне, мгновенно «переключается», отвечая торговке в грубовато-упрощенной словесной манере.

Образ Панны трактован как балетный персонаж. По-видимому, на мысль о подобной интерпретации навело композитора то обстоятельство, что Сотникивна не произносит в повести ни единого слова (исключение составляет ее беседа с бурсаками, когда Ведьма принимает вполне реальное, «человеческое» обличие Старухи $)^{4}$.

Итак, В. Губаренко, в сопоставлении с Н. Гоголем, значительно расширяет народную образную сферу (добавленный к сюжетно-словесному ряду Пролог, хоры I действия и Эпилога), даже создавая в I акте некий обобщенный образ народа, наподобие того, что выведен Мусоргским в «Борисе Годунове» (о музыкально-сценических особенностях этой сцены подробнее см. ниже). В оперу введен также отсутствующий в повести образ женщины «из народа». Это, одновременно, и подруга Хомы - «молодая вдова, продающая ленты, оружейную дробь и колеса» на рынке [2, 157], и старуха, комментирующая рассказы Дороша о проделках Панны-Ведьмы [2, 171], и помощница старой кухарки Сотника, ужаснувшаяся произошедшей с Хомой внезапной перемене («Ах, Боже мой! Да ты весь поседел...» [2, 178].

Хома, за счет введения отсутствующей в первоисточнике сцены, где он впервые увидел Панну, и сольного номера - песни раскрывается, прежде всего, как герой лирический (напомним, что у Гоголя Хома не испытывает к Сотникивне никаких чувств, впервые увидев ее уже мертвой).

Образ Панны загадочен, неоднозначен... Прекрасная, надменная (эпизод «Сотникивна - Стецько»), любящая, ревнивая, страстная (соло из I действия) женщина, и - вселяющая ужас мстительная ведьма (сцена - полет; буйство нечистой силы в церкви). Эволюция главной героини оперы, по замыслу композитора, решается при помощи только балетных средств.

Таким образом, мы можем говорить о существовании в фабуле «Вия» Губаренко взаимодействия жизнеутверждающей силы, воплощенной в народных образах и, прежде всего, в образе Хомы, и стихии потустороннего, с которой тесно связана главная героиня Панна.

Изменения, осуществленные в либретто относительно текста первоисточника, акцентируют наше внимание на любовном конфликте 
между главными героями, которые существуют в разных плоскостях, принадлежат разным мирам (что подчеркнуто и в использовании различных для воплощения образов главных героев музыкально-сценических средств). Краткость их союза запрограммирована заранее, а итог может быть лишь один - гибель обоих влюбленных.

Для музыкальной композиции оперы большое значение имеют три лейтмотива.

Первый лейтмотив - хор бурсаков «Радость, радость велия! День настал веселия!», шире - гимн счастливой, полнокровной жизни открывает оперу (Пролог) и сопровождает каждое появление на сцене бурсаков (последний раз звучит в Эпилоге, где Тит и Тиберий вспоминают своего погибшего друга Хому). Кроме того, на этой теме построены обе интерлюдии. Лейтмотив начинается нисходящим ходом c V на I ступень (с пропуском II) с последующим восхождением на VI, а затем VII. М. Черкашина подчеркивает близость этой темы-раскачки «распевам-юбиляциям и выделяющимся на фоне общих форм движения мотивным зернам партесных концертов» [12, 115].

Вторая лейттема, семантически связанная с миром насилия и жестокости Сотника и его помощников - Дороша и Свирида, относится к другому, инструментальному типу тематизма, и напоминает тему-серию. Именно этот лейтмотив становится производным для появляющихся за ней тем потусторонних - Панны (ее основного лейтмотива) и Вия. (Здесь действует одна из закономерностей, свойственных работе Губаренко над тематизмом вообще. Относительно долгие темы композитор расщепляет на несколько самостоятельных субтем, раскрывающих в первоначальном тематическом образовании более глубокие семантические уровни $[5,190])$. Так Губаренко удается продемонстрировать, что в опере зло потустороннее взаимодействует со злом земным, человеческим ${ }^{5}$, возможно - им порождено, вызвано, призвано к появлению/проявлению в реальном мире.

Лейтмотив Панны основан на «повторении изложенного параллельными квартовыми аккордами раскачивающегося трехзвучного мотива с начальной нисходящей септимой, как бы неким немым вопросом и гипнотическим взглядом странной красавицы» $[12,114]$. Эта тема, как и предыдущая тема «сотникивщины», впервые появляется в первом действии, а затем возвращается в разных вариантах как одно из ключевых музыкально-тематических образований оперы.

Еще один лейтмотив Сотникивны - тема Lamento: на нем строится музыкальный материал единственного в опере балетного соло 
Панны ${ }^{6}$ (в том же I акте), где внезапно вспыхнувшая в ее душе любовь вызвала поток других противоречивых чувств, вызвавших окончательное перерождение героини в Ведьму - «мрачное смятение, ревность» (сольный танец I акта $[4,97])$, стремление к безраздельному обладанию предметом ее страсти (подчинение и «оседлание» Хомы из второго действия) и пр. Поэтому эту тему можно условно обозначить как тему Панны страдающей и любящей.

С образом Сотникивны связан целый комплекс интонаций, развивающихся вариантно или методом симфонической разработки, переплетающихся друг с другом и сопоставляющихся с другим музыкальным материалом оперы. Практически везде, где присутствует Ведьма или фигурирует ее имя, в оркестровой партии проходит «обыгрывание» двух типов тематизма, семантически связанных с полярными чувствами, которые испытывает Панна - человек и Панна - ведьма. Это мотивные образования состоят, соответственно, из скачков на септиму и другие широкие интервалы, и, наоборот, из предельно узкой секундовой интонации - стона.

Образ Вия, воплощающего страшную, уничтожающую все живое, потустороннюю силу, которой не смог противостоять Хома, воплощен в теме - «поступи», не несущей функцию лейтмотива. Этот мотив сопровождает выход фантастического чудовища - кульминационный момент столкновения в опере добра и зла (картина четвертая) и завершает ряд тем контдействия, появляющихся последовательно и «произрастающих» одна из другой:

тема сотникивщины $\rightarrow$ тема Панны-Ведьмы $\rightarrow$ тема Вия

Из лейтмотива каникулярного гимна бурсаков также формируются самостоятельные тематические образования. Это рефрен «Ярмарка» из первого действия и некоторые фрагментарные мотивы - характеристики персонажей из той же сцены - торговок, Бубличницы и др.

На музыкальной архитектонике I акта подробно останавливается в своей статье М. Нестьева, обращая особое внимание на используемый композитором прием «индивидуализации народной массы» [9, 40]. У Торговки сластями, Продавца посуды, Веселого мужика, Цыгана, Стецько, той же Бубличницы есть своя музыкальная реплика в вокальной или оркестровой партии. Индивидуализированные интонация, ритм, опора на определенный жанр создают неповторимый облик каждого второстепенного, на первый взгляд, героя. Ведь в совокупности все эти персонажи «второго плана» воплощают единый 
образ народа, шире - самой жизни, полнокровной, яркой, многокрасочной, которая становится «питательным источником для вампирических устремлений всякой нечисти» $[12,115]$.

Хор выступает в опере как активный участник действия (Пролог, I акт; картина третья, четвертая - хор исполняет партию Вия - III действия; Эпилог) и комментатор событий (третья картина III акта отчасти), и - выполняет функцию фона, «оркестровой краски» (создает эффект «храмовой чистоты» за счет применения мажоро-минорных аккордов, исполняемых «закрытым ртом» в сопровождении молитв Хомы в четвертой картине третьего действия). При этом хор может быть и народным, и «потусторонним» (в этом случае он исполняет свою партию за сценой), то есть семантически связанным с персонажами как действия, так и контрдействия.

Единственный в опере сольный номер Хомы «Ты скажи мне, соловейко» раскрывает духовный облик героя. Это «один из наиболее интересных примеров использования песни в «Вие», трактованной как центр развернутой оперной сцены драматически действенного характера. Словесный текст номера имеет фольклорное происхождение, но музыка написана композитором без опоры на конкретный фольклорный жанр. Вместе с тем, в музыке достигнут синтез черт украинских лирических и эпических песен, подчеркнуто свойственное последним импровизационное начало». «Навевающие грусть ночные трели соловья сопоставляются» по смыслу «с любовной тоской бездомного бурсака», при этом «мужественная сдержанность вокальной мелодии сочетается с полным экспрессии, приобретающим образную самостоятельность оркестровым сопровождением. Хома Брут ощущает в таинственной ночи, исполненной томления и загадочных звучаний, дыхание собственной судьбы. Он страшится неведомого будущего и одновременно всей душой устремлен ему навстречу...» $[13,65]$.

Выразительные средства, используемые композитором для характеристики сфер добра и зла, восходят к прочной традиции русской и украинской музыки: опора на мелодику, гармонию, приемы развития фольклорных отечественных жанров, партесного концерта и жанров церковного пения - в первом случае, и - инструментальный характер тематизма, диссонирующие вертикальные комплексы с секундами, квартовые параллельные аккорды, отсутствие развития лейтмотивов (кроме тем, связанных с образом Панны, входящим в группу персонажей как действия, так и контрдействия) - во втором. 
Сквозное музыкально-событийное развитие оперы «цементируют» репризные повторы, система лейтмотивов, четкий сценический концентрический план.

Подводя итоги, сформулируем выводы исследования. В истории о любви Хомы и Панны В. Губаренко счастливому объединению двух влюбленных помешала их принадлежность к двум пространственно-временным и, одновременно, нравственно-философским «полюсам» - добра и зла. Вспыхнувшее между Человеком и Ведьмой чувство разрушает их обоих и приводит к трагическому исходу. Вспомним: и танцевальное соло Панночки, и песня Хомы Брута «Ты скажи мне, соловейко» пронизаны страданием, и хотя Панна полна злобы и ревности, а философ - тоски по ласке, красоте, душевному теплу и покою, оба героя предчувствуют, что им не дано обрести счастья, что они обречены на гибель.

Мир Хомы - мир молодости, активной, полнокровной, «льющейся через край» жизни. Образ Хомы воплощает вечный поиск идеала, стремление к свободе, к любви. Панна живет в другом измерении, где обитают загадочные потусторонние силы, вторгающиеся в обыденную реальность. Композитор подчеркивает основную черту в облике главной героини - необыкновенную, захватывающую дух красоту. Но эта красота опасна и выступает как знак скорой смерти для того, кто посмел ею залюбоваться.

Особое внимание композитор акцентирует на идее несоответствия Сотникивны с миром, в котором живет ее возлюбленный. Даже те родственные узы, которые связывают ее через Сотника - отца с миром живых, не могут приблизить Панну к Хоме. Ведь и Сотник, и его «свита» выступают как своего рода представители зла, но зла земного, вполне реального. Ведьма в порыве гнева и отчаяния, понимая невозможность своего душевного сближения с Хомой и, тем самым, избавления ее от одиночества и изоляции (последние подчеркнуты интерпретацией образа героини как балетного персонажа), насылает на Брута колдовские чары. Хома отчаянно сопротивляется, но ему некому помочь, тогда как за Панной стоят потусторонние силы, легион наводящих ужас «крылатых и хвостатых чудовищ» во главе с их королем - Вием.

Образ Вия, на наш взгляд, у Н. Гоголя двойственен, и эта полярность была чутко уловлена и передана средствами музыкального театра В. Губаренко. Глава гномов всемогущ - и, одновременно, беспомощен: «тяжело ступает, поминутно оступаясь», «длинные веки его 
опущены до самой земли» $[2,183]$. Да и сами существа, окружающие свое божество, в том числе и Ведьма, не обладают такой всепобеждающей силой, которой невозможно было бы воспротивиться. Вспомним: Хома очертил вокруг себя круг, за которым Панна и чудовища его просто не видели. То есть философ нашел способ борьбы с нечистой силой. И когда наступил «решающий момент», и все сонмище кинулось поднимать Вию веки, Хома и в этом случае знал, что ему необходимо предпринять, чтобы остаться невредимым - попросту не смотреть. Но философу было... любопытно (!), и он глянул, не вытерпел. Недаром в эпилоге Гоголь устами Тиберия дает свои шуточные комментарии по поводу произошедшей с Хомой истории: не побоялся бы, дескать, философ ведьмы, «плюнул ей на хвост», и ничего она не смогла бы с ним сделать.

Скорее всего, говорит нам писатель, история с Хомой и Ведьмой - народное предание. Но, вполне вероятно, что мы имеем дело и с историческим фактом, обросшим невероятными подробностями и вымыслом. Ведь, как пишет сам Гоголь, «материя о ведьмах» для нашего народа «неисчерпаема» [2, 172].

Эти чрезвычайно важные семантически особенности концепции гоголевского сочинения были по-своему интерпретированы Губаренко в опере. Композитор ввел фантастическую историю любви Хомы и Панны в круговорот вполне реальных событий, происходящих на ярмарке, в ночь на Ивана Купала. Кроме того, в опере драматические сцены перемежаются комическими. (Так, в картину ярмарочного веселья вторгается эпизод избиения Цыгана, оплакивание Панны происходит «параллельно» с веселым застольем у Бубличницы, сцена гибели Хомы сменяется праздничным финалом.) Вместе с тем происходит и диффузия противоположностей: Панна предстает как существо, принадлежащее обоим мирам - реальному и потустороннему (лейтмотивы Панны - ведьмы и Панны - девушки), а зло «земное» оказывается тесно связанным (общим интонационным комплексом) со злом ирреальным.

У Н. Гоголя серьезное и смеховое находятся в свободном диалоге, что реализуется в их размежевании, оппозиции и - взаимопроникновении. Эта особенность литературного стиля писателя, столь ярко воплотившаяся в его «Вие», нашла свою реализацию и в опере-балете В. Губаренко. 


\section{ПРИМЕЧАНИЯ}

${ }^{1}$ Повторенные дважды фразы выделены в таблице курсивом.

${ }^{2}$ Н. Гоголь: «Вий - есть колоссальное создание простонародного воображения...» $[2,147]$.

${ }^{3}$ Т. е. учеником старших классов, тогда как до этого момента Тиберий был ритором - учеником младших классов.

${ }^{4}$ Об идее разграничения мира реального и мира фантастического как, соответственно, «вокально-речитативного» (вербального) и «танцевального» (невербального) и ее семантике [12, 113-115].

5 Достаточно вспомнить эпизод, в котором Сотник силой принуждает Хому читать молитвы в церкви, или Дороша, с остервенением избивающего Цыгана.

${ }^{6}$ При постановке оперы в 1980 г. во время исполнения сольной партии Хомы «Ты скажи мне, соловейко» Панна, внимающая призыву любимого, исполняет еще одно соло - танец (подробнее об этом см. [9, 40]).

\section{СПИСОК ЛИТЕРАТУРЫ}

1. Асафьев Б. Об опере. Л.: Музыка, 1976. 336 с.

2. Гоголь Н. В. Вий. Собр. соч.: в 6 томах. Т. 2. М.: Гос. изд-во худ. лит., 1949. C. $147-184$.

3. Грибкова Ю. Сміх крізь сльози М. Гоголя в контексті романтичної іронії. О природе смеха. Одесса: ООО Студия «Негоциант», 2001. Вып. 2. С. 102-106.

4. Губаренко В. Вий. Опера-балет. Клавир. Факсимильное издание. К.: Муз. Украина, 1990. 288 с.

5. Драч I. Композитор В. Губаренко: формула індивідуальності / Сумський державний педагогічний університет ім. А. Макаренка. Суми, 2002. 227 с.

6. Ермилов В. Н. В. Гоголь. М.: Сов.писатель, 1952. 294 с.

7. Краснопольська Т. Національні мотиви творчості В. Губаренка Українська музика: зб. статей. К.: Музична Україна, 1972. С. 54-59.

8. Матюшина И. Ирония как принцип постмодернистского романа. O природе смеха. Одесса: ООО Студия «Негоциант», 2001. Вып. 2. С. 125-130.

9. Нестьева М. В союзе с композитором. Сов. музыка. 1985. № 8. С. 39-46.

10. Нестьева М. Советская опера 70-80-х годов (на примере некоторых образцов многоактной оперы). Муз. театр. События. Проблемы. М.: Музыка, 1990. C. $12-48$.

11. Холопова В. Формы музыкальных произведений. СПб.: Лань, 2001. $496 \mathrm{c}$.

12. Черкашина М. Вариации на тему «Вия». Музыка и театр на перекрестке времен: в 2 т. Т. 2. Сумы: Наука, 2002. С. 113-119.

13. Черкашина М. Проблема соотношения слова, музыки и действия в современной украинской опере. Музыка и театр на перекрестке времен: в 2 т. T. 2. Сумы: Наука, 2002. С. 56-78.

14. Яворський Е. В. Губаренко. К.: Музична Україна, 1972. 50 с. 


\section{REFERENCES}

1. Asafyev, B. (1976). About opera. - Leningrad: Muzyka [in Russian].

2. Gogol, N. (1949). Viy. Collected works: in 6 vol. - Moskow: Gos. izd. hud. lit., V.2, 147-184 [in Russian].

3. Gribkova, Y. (2001). Gogol laughter through tears in the context of romantic irony. About the nature of laughter. - Odessa: OOO studia «Negociant», 102-106 [in Russian].

4. Gubarenko, V.(1990). Viy. Opera - balet. Clavier. Facsimile edition. - Kiev: Muz. Ukraina [in Russian].

5. Drach, I.(2002). Composer V. Gubarenko: formula of individuality. - Sumy [in Ukrainian].

6. Ermilov, V. (1952). N. Gogol. - Moskow: Sov. pisatel [in Russian].

7. Krasnopolska, T. (1972). National motives of creativity of V. Gubarenko. Ukrainian music. Col. of articles. - Kiev: Muz. Ukraina, 54-59 [in Ukrainian].

8. Matushina, I. (2001). Irony as the principle of postmodern novel. About the nature of laughter. - Odessa: OOO studia «Negociant», 125-130 [in Russian].

9. Nestieva, M. (1985). In the union with the composer. Sov. music, 8, 39-46 [in Russian].

10. Nestieva, M. (1990). Soviet opera of 70-80 years (on the example of some samples). Musical theatre. Developments. Problems. - Moskow: Muzyka, 12-48 [in Russian].

11. Kholopova, V. (2001). Forms of music pieces. - Saint Petersburg: Lan [in Russian].

12. Cherkaszina, M. (2002). Variations on a theme of «Viy». Music and theater at the crossroads of times: in 2 vol. - Sumy: Nauka, V. 2, 113-119 [in Russian].

13. Cherkaszina, M. (2002). The problem of the ratio of words, music and action in the modern Ukrainian opera. Music and theater at the crossroads of times: in 2 vol. Sumy: Nauka, V. 2, 56-78 [in Russian].

14. Yavorsky E. (1972). V. Gubarenko. - Kiev: Muz. Ukraina [in Ukrainian]. 